\title{
Correction to: A Proof of the Bloch Theorem for Lattice Models
}

\author{
Haruki Watanabe ${ }^{1}$ \\ Published online: 14 February 2020 \\ (c) The Author(s) 2020
}

\section{Correction to: Journal of Statistical Physics (2019) 177:717-726 https://doi.org/10.1007/s10955-019-02386-1}

The article "A Proof of the Bloch Theorem for Lattice Models." written by Haruki Watanabe was originally published electronically on the publisher's internet portal (currently SpringerLink) on 17 September 2019 without open access. With the author(s)' decision to opt for Open Choice the copyright of the article changed on 10th February 2020 to (C) The Author(s) 2019 and the article is forthwith distributed under the terms of the Creative Commons Attribution 4.0 International License (http://creativecommons.org/licenses/by/4.0/), which permits use, duplication, adaptation, distribution and reproduction in any medium or format, as long as you give appropriate credit to the original author(s) and the source, provide a link to the Creative Commons license and indicate if changes were made.

The original article has been corrected.

Open Access This article is licensed under a Creative Commons Attribution 4.0 International License, which permits use, sharing, adaptation, distribution and reproduction in any medium or format, as long as you give appropriate credit to the original author(s) and the source, provide a link to the Creative Commons licence, and indicate if changes were made. The images or other third party material in this article are included in the article's Creative Commons licence, unless indicated otherwise in a credit line to the material. If material is not included in the article's Creative Commons licence and your intended use is not permitted by statutory regulation or exceeds the permitted use, you will need to obtain permission directly from the copyright holder. To view a copy of this licence, visit http://creativecommons.org/licenses/by/4.0/.

Publisher's Note Springer Nature remains neutral with regard to jurisdictional claims in published maps and institutional affiliations.

The original article can be found online at https://doi.org/10.1007/s10955-019-02386-1.

\footnotetext{
$凶$ Haruki Watanabe

haruki.watanabe@ap.t.u-tokyo.ac.jp

1 Department of Applied Physics, University of Tokyo, Tokyo 113-8656, Japan
} 